\title{
ISLAMIC ARTS MUSEUM, MALAYSIA: EDUCATIONAL TOOL FOR REVIVING ARCHITECTURAL HERITAGE
}

Dr. Djamel Dilmi, Assistant Professor

\author{
College of Architecture, Design and Planning \\ Qassim University, KSA \\ Email Address: djamel@qec.edu.sa / \\ dilmi1@yahoo.com
}

\begin{abstract}
The Islamic art and architecture have played a significant role in the development of historic cities in the Muslim world; they were developed through time in response to socioeconomic and cultural needs of the society. The paper will focus on the experience of the Islamic Arts Museum in terms of its role in raising public awareness about Islamic art and architecture through its building that combines modernity and heritage in unique Islamic architectural style and educational programs and activities that educate people about conservation of Islamic heritage. The aim of this essay is to present the experience of IAMM in promoting Islamic art and architecture in order to share experience as a successful model. To achieve this aim the existing conditions of this museum were examined in terms of its building, decorated element, cultural activities and conservation programs using traditional ways and modern technologies. A broad range of information was collected from various sources and through a field survey carried out in the selected museum from modern country leading development in the Muslim world. The collected information was analyzed with particular regard to the special character. This paper is an attempt to address the important issues of educational programs that raise public awareness about heritage through interior design and display of artifact from different regions of Muslim world matters that have been raised in many museums around the world and it is hoped that it is going to be a significant contribution to the subject of reviving Islamic architecture in the modern world.
\end{abstract}

Keywords: Islamic art and architecture, museum, modernity and heritage, conservation programs, educational activities.

\begin{abstract}
Abstrak
Seni dan arsitektur Islam telah memainkan peran yang sangat penting dalam perkembangan kota-kota bersejarah di dunia Muslim; dibangun sepanjang masa sebagai respon terhadap kebutuhan sosial ekonomi dan budaya dari masyarakatnya. Makalah ini akan difokuskan pada pengalaman Museum Seni Islam dalam perannya meningkatkan kesadaran publik tentang seni dan arsitektur Islam melalui arsitekturnya yang memadukan modernitas dan warisan budaya Islam di dalam gaya arsitekturnya, program-program edukatif, dan aktivitasaktivitas yang mendidik masyarakat mengenai pelestarian warisan budaya Islam. Tujuan dari makalah ini adalah untuk menyajikan pengalaman IAMM di dalam mempromosikan seni dan arsitektur Islam, dalam rangka berbagi pengalaman sebagai salah satu model yang berhasil. Untuk itu, pembahasan mengenai museum ini akan meliputi bangunannya, elemen dekorasinya, aktivitas-aktivitas kulturalnya, dan program-program konservasi menggunakan cara-cara tradisional dan teknologi modern. Informasi yang sangat luas mengenai topik ini diperoleh dari berbagai sumber dan survei lapangan di museum terpilih dari negara modern yang memimpin pengembangan di dunia Muslim. Makalah ini merupakan sebuah upaya untuk merespon isu-isu penting dari program-program edukatif yang meningkatkan kesadaran publik tentang warisan budaya melalui desain interior dan cara menampilkan artifak dari berbagai wilayah di dunia Muslim yang telah diupayakan di berbagai museum di berbagai belahan dunia. Diharapkan, terdapat kontribusi signifikan terhadap subjek revivalisasi arsitektur Islam di dunia modern.
\end{abstract}

Kata kunci: seni dan arsitektur Islam, museum, modernitas dan warisan budaya, program konservasi, aktivitas edukatif 


\section{Introduction}

The Islamic Arts Museum Malaysia is one of the world's leading institutions dedicated to Islamic art field that is attracting more interest than ever, spanning all great Islamic civilizations and all corners of the globe. The scholarly field of Islamic art is a growing one and the Al-Bukhary Foundation has recognized the importance for the establishment of a museum that would preserve artifacts from Islamic civilizations and act as a centre of education for the study of the art, culture and history of Islam. Light and modernity are the basic elements that made a departure point of the architectural concept of this museum in Malaysia. Away from the hassle and basal and noisy streets of Kuala Lumpur city, this museum is located on one of greenest areas of the city. The sense of calm and order is created in its stark white façade and blue domes and conveyed throughout the entire interior spaces. The decoration of the building is one of the special characters that expressed the great architectural achievements of Islamic lands which were of profound influence on this building that has successive experience in displaying the artifacts of brilliant past civilizations to their best advantage. As a museum of Islamic art dedicated to the preservation of ancient cultures, built at a time when the world was at the brink of the $21^{\text {st }}$ century, it was imperative that the Museum be an environment that was sleek and modern.

\section{The Architecture of the Museum Building}

The conceptual design of the museum building was created by the Italian architect, Roberto Monsani by an imposing, geometric structure, lightened by its use of glass paneling and lofty dimensions, and divided into three separate wings over a gently sloping land area. Clad in gridded panels of white marble, the Museum is surrounded by tropical foliage ${ }^{1}$. With its shimmering glass windows, white façades and glittering blue domes, it stands as a welcoming oasis of Islamic art and culture. Its white marble walls recall the opulent monuments of Mughal India, whilst its grand portico and impressive size bring to mind the great mosques and caravanserais of medieval Iran (Figure 1).

The great front portal of this building was presented in form of iwan, which is an attractive and welcoming element for the museum visitors pass through from the main street into its lobby. An architectural form originating in pre-Islamic Sasanian times, the iwan served as a monumental entrance, this design has been used for palaces, mosques, schools, and private homes. During medieval Islamic times, the construction of colossal entrances and gateways were seen as testimony to a ruler's power and strength. A vaulted hallway with a pointed arched opening encased within a rectangular frame, the iwan is a popular structure in Central Asia and Iran in particular ${ }^{2}$. The iwan of the Islamic Arts Museum Malaysia, however, is recreated in an abstract form, where the vaulted hall and pointed archway no longer exist, leaving only the rectangular framework (Figure 2). Not only does this form continue the repetition of rectangular frames carried throughout the entire building architecture, it creates a quietly restrained façade for a building devoted to the preservation of Islamic art and culture; art and culture that is inextricably bound to religion, yet is preserved and presented in an ultimately aesthetic approach that reinforces the museum's position as a temple of art and not an institution of religious dogma.

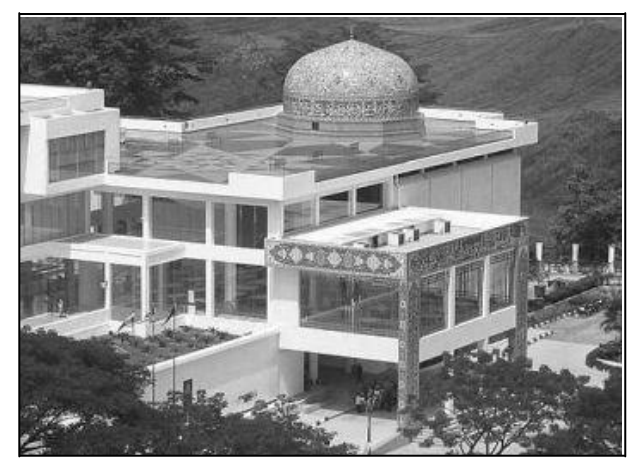

Figure 1. The white marble walls recall the opulent monuments of Mughal and Persian Style

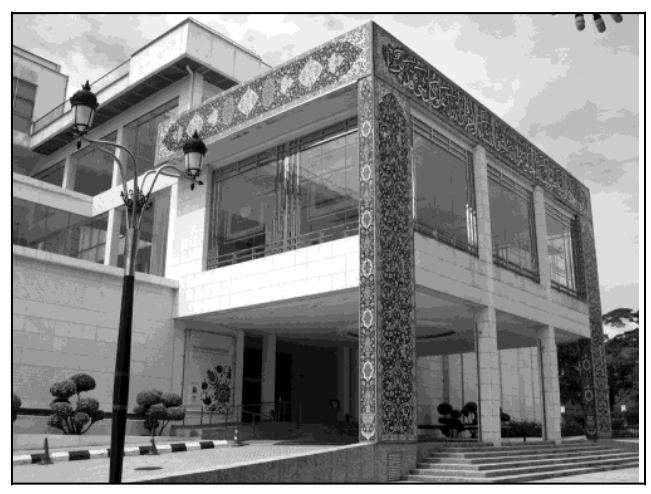

Figure 2. The iwan of the Islamic Arts Museum Malaysia leaving only the rectangular framework

The five turquoise-coloured domes are now a landmark on the Kuala Lumpur skyline and they are a main element in the special feature of the museum building. These elegant domes characterize the interior of the museum, each exclusive in design. The interiors of the four domes and the exterior of 
the inverted dome are all decorated with carved and molded gypsum. The product of Uzbekistani craftsmanship, the four dome interiors are painted in warm tones of terracotta, blue and lavender, with gilt detailing ${ }^{3}$. The most exceptional is the inverted dome, however, has no color embellishment and its pure white surface is adorned with elegantly carved coiling arabesque tendrils relieved by two rows of mirror and gilt cartouches. The rim of the dome is inscribed with the opening verse of the Qur'an in gold (Figure 3).

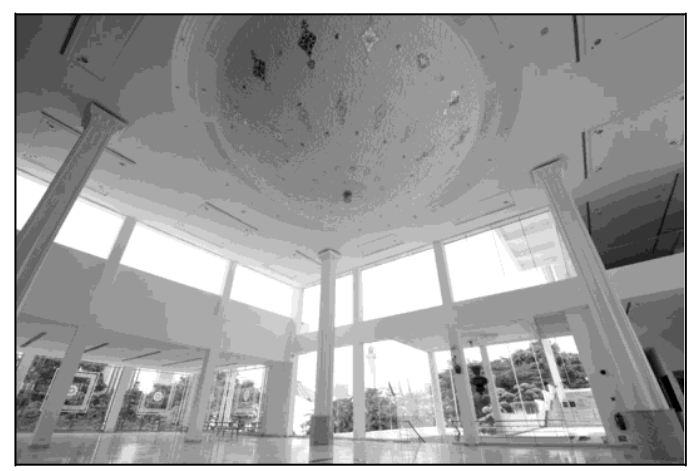

Figure 3. The inverted dome is adorned with elegantly carved coiling arabesque

\section{Art and Symbolism of Islamic Architecture}

In all mediums of Islamic art, there is an emphasis on the repetition of motifs. In the Museum, this is not only seen in the artifacts in its collections, but also in the detailing of the museum building. Besides the columns and domes, the same materials are used throughout the building reinforcing the unity that is Islam and one of the main aspects of Islamic art. The museum is not a space of rich textures. Instead, the plain white walls and smooth surfaces create a neutral platform for the often opulent artifacts of the most splendid civilizations of Islam. Far from being austere, however, the building environment is a welcoming one; with the warm glow from the carefully lit vitrines and recessed lights, comforting beige marble floors and warm beech railings that complement the beech tones of the wall display cases (Figure 4).

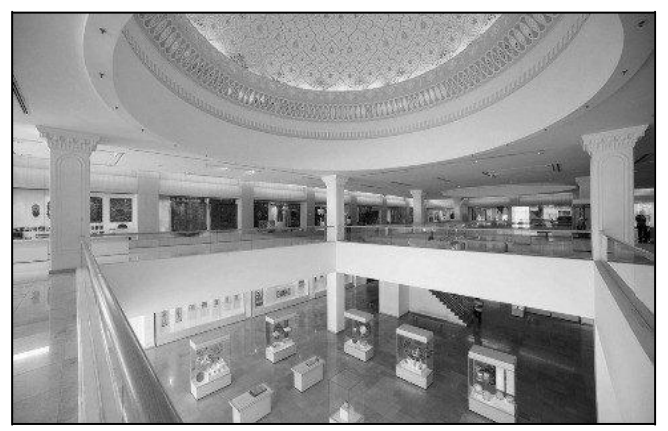

Figure 4. Various artifacts are displayed in display cases
Small amounts of natural light are permitted in the inner sections of the top floor of the permanent galleries. Filtered natural light makes its way into the museum through the window paneling above the wall cases that line the Textile, Jewellery and Arms and Armor Galleries on the fourth floor. The repeated arches of the muqarnas were of inspiration to the architect to create abstract muqarnas forms in tempered glass. Five layers of tempered glass were stacked upon each other to create four rows of arched, scale-like patterns, introducing a new decorative element, while incorporating a form that appears throughout the building in a different medium. This application of the same motif or idea in a wide range of mediums is a characteristic of Islamic decoration and is further revealed as one examines and compares the vast range of artifacts in the museum collection.

From the fourth floor, the museum visitor can step out onto the Islamic Arts Museum's viewing terrace, a large rooftop area surrounding the museum's main dome (Figure 5). The floor of the terrace is made up of turquoise and cobalt blue tiling in geometric and stellar designs. Not only does the terrace enable visitors to examine the main dome at close range, it also provides them with an excellent view of the ever-expanding Kuala Lumpur city skyline that unfolds around them; from lush greenery on the left, to an eclectic blend of high rise office blocks, colonial architecture, the modern Islamic forms of the mosque and other prominent buildings of the city and towering sky-scrapers ${ }^{4}$. A fitting conclusion to the museum tour of art and history, the integration of the museum with its surroundings serves as a reminder of the necessity for the preservation of cultural heritage in the midst of mankind's relentless pursuit of development and modernization.

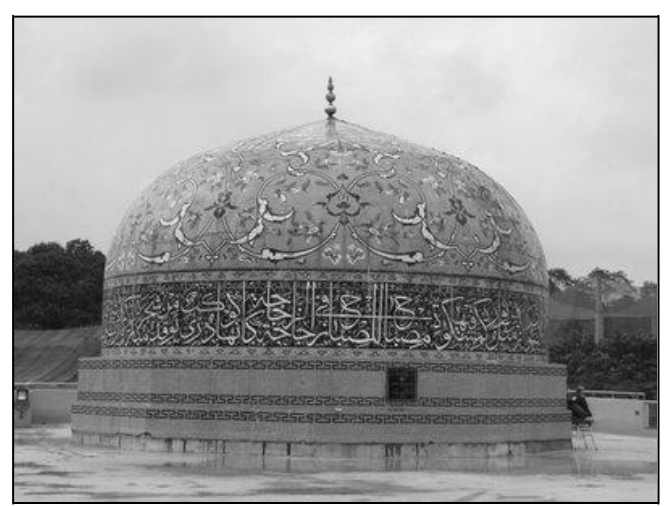

Figure 5. The viewing terrace, is a large rooftop area surrounding the museum's main dome 


\section{Decoration of the Building}

Islamic decoration does not emphasize the actual mechanics of a building, the balance and counterbalance of loads and stresses. Instead, Islamic decoration is a part of the architectural tradition that aims at a visual negation of the reality of weight and the necessity of support. Because little furniture is traditionally used for daily life in Islam, decoration contributes to the creation of a sense of continuous space that is a hallmark of Islamic architecture.

Water and light are also of paramount importance to Islamic architectural decoration as they generate additional layers of patterns and - just as happens with surface decoration - they transform space. Space is defined by surface and since surface is articulated by decoration, there is an intimate connection in Islamic architecture between space and decoration. It is the variety and richness of the decoration, with its endless permutations, that characterizes the buildings rather than their structural elements, which are often disguised.

Light is the symbol of divine unity, light functions decoratively by modifying other elements or by originating patterns. With the proper light, pierced facades can look like lacy, disembodied screens. Natural light has added a dynamic quality to the architecture of the museum, extending patterns, forms and designs into the dimensions of time. (Figure 6).

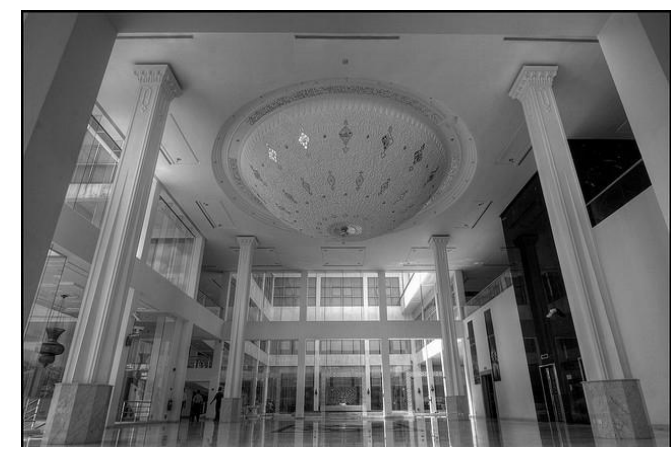

Figure 6. Natural light has added a dynamic quality to the architecture of the museum

\section{Galleries and Display of Objects}

The galleries of the Islamic Arts Museum Malaysia are spacious, minimally adorned, with clean lines and subtle detailing. Unlike most museums that are made up of groups of rooms or corridors, this museum's galleries are all connected as one vast space, with areas that flow throughout the museum's different wings and levels (Figure 7). This elimination of precise division permits the visitor uninterrupted movement from one area to the next and reflects the Islamic spirit of continuity, a fundamental feature of Islamic decoration. Square, white columns and pilasters provide subtle relief from what could otherwise be a monotonous stretch of space. While recalling the seemingly endless pillared arcades of the great mosques of Islamic civilizations, the galleries nevertheless retain a sense of order and simplicity. The vitrines with their precious contents stand serenely in simple arrangements and each gallery relates to the next in this uniformity of display ${ }^{5}$.

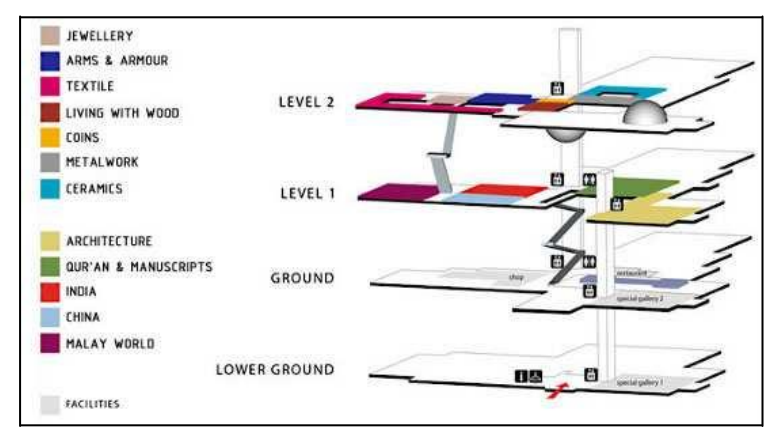

Figure 7. The galleries of the museum are all connected and divided into wings and levels

\section{Architecture Gallery}

The museum has dedicated on gallery for Islamic architecture to enhance the richness of this art of building in Islam, this art was one of the earliest expressions of Islamic cultural identity and has retained its importance ever since. Architecture is best experienced in its original form and is not something that is easily conveyed within the confines of gallery walls and showcases. Nevertheless, the Islamic architecture gallery devoted to architecture attempts to provide the viewer with a survey of splendor of the monumental art and this monumental art form in a museum setting has been achieved by using a comprehensive collection of scale models of prominent buildings around the Islamic world and information panels tracing the development of Islamic architecture, as well as original artifacts of Islamic architectural ornamentation such as tiles and carved wooden panels ${ }^{6}$. Some of the most important monuments in Islam are displayed here in the form of threedimensional architectural models: These ranges from the colossal grandeur of the holiest mosques in Islam Mecca's Masjid al-Haram and site of the holy Kaabah, the Prophet's Mosque in Medina and the Dome of the Rock in Jerusalem, one of the first examples of Islamic architecture (Figure 8). Additionally, mosques and mausoleums from different periods and regions of the Muslim world 
offer a comparison in styles and design. Every corner of Islam is covered in miniature, including the widely overlooked mosques of China and Southeast Asia.

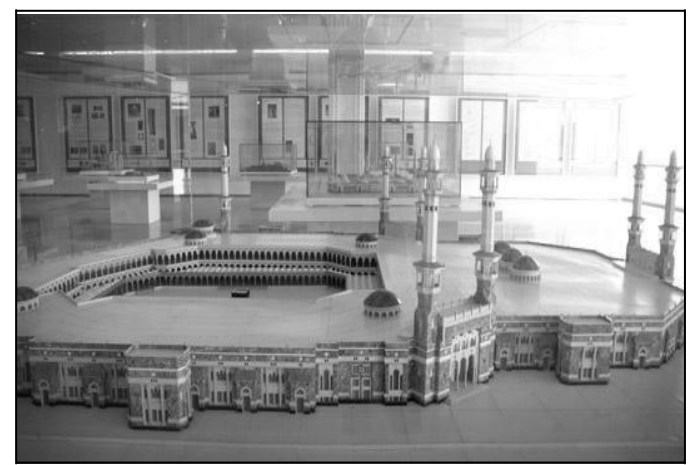

Figure 8. The model of al-Masjid al-Haram in Makkah is displayed in architecture gallery

To give a more intimate impression of these sacred spaces, the gallery includes a re-creation of a mosque interior. There are several ways to approach the architecture of Islam. From a technical and practical viewpoint, there are the techniques of construction and functionality of the buildings. The Architecture Gallery in this museum incorporates a section devoted to architectural ornament, featuring, mainly fragments of wall friezes, individual pieces of faience and stone or wood carvings. The motifs are characteristic of Islamic art: repetitive geometric patterns and arabesques, calligraphic inscriptions, and vegetal and floral motifs.

\section{Display and Design}

The art objects on display range from the tiniest pieces of jewelers to one of the world's largest scale models of the Masjid al-Haram in Makkah. The aim is to create a collection that is truly representative of the Islamic world. The over helming lesson is that the design of a museum and galleries is a careful balance of a diversity factors. The architectural design is harmonizing with the message of displays, while the needs of conservator and visitors must be equally resolved. The experience also serves as an illustration of how introducing new designers to the exercise can invigorate the task. At the same time it underlines the importance of capitalizing on the wealth of knowledge of those within museum and of the external consultants and experts in manufacture.

The Islamic Arts Museum Malaysia has two floors of permanent galleries and two special galleries for temporary exhibitions. The permanent galleries are categorised by artefact material or field of study. Located on Level 3 of the IAMM are some exceptions, the India Gallery, China Gallery and Malay World Gallery. These three galleries serve as representations of the diversity of Islamic peoples and the multi-cultural heritage of Malaysia. Not only is the majority of Malaysia's population made up by these three ethnic groups, the Malays, Chinese and Indians, but the two theories of Islam's introduction to the Malay Archipelago hypothesise that Islam arrived either through Arab and Indian merchants via the west, or from Chinese Muslims in the east. The remaining galleries of the IAMM are the Architecture Gallery and the Qu'rans and Manuscripts Gallery, also located on Level 3; and the Ceramics and Glass Gallery, Metalwork Gallery, Coins Gallery, Woodwork Gallery, Arms and Armour Gallery, Jewellery Gallery, and Textiles Gallery, all on Level 4. Within each gallery, the collections are displayed thematically, according to chronology, region or technique of production (Figure 9).

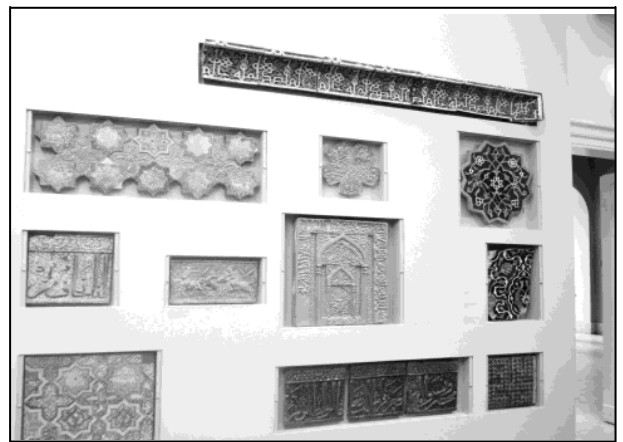

Figure 9. The collections are displayed according to chronology, region or technique of production

The history of Islam and the amazing range of styles, techniques and trends are so varied that it is difficult to adopt a formal approach in the presentation of the collections. Gathered within the halls of the galleries are pieces that may or may not illustrate the most significant aspects of a particular region or dynasty. Some pieces come to be here through the generosity of private downers or lenders, others through the museum's acquisition policy. Collectively, they are organised to give the museum visitor a clearer idea of the multiple aspects of Islamic art and culture: the ethnographic artefacts of great civilisations, the decorative techniques and materials used and the characteristics of Islamic art.

The first, the Architecture Gallery includes an introduction to the most important elements of mosque architecture as well as brief mention of the Islamic palace and mausoleum, two of the other most prominent forms of Islamic monumental 
buildings. A branch of the Architecture Gallery is the celebrated Ottoman Room, sponsored by the Standard Chartered Banking Corporation ${ }^{7}$. A $19^{\text {th }}$ century room from an Ottoman Syrian noble house, original panels and windows have been carefully reconstructed in the museum to create an example of the opulence and grandeur of the last magnificent empire of Islam (Figure 10). The introduction of each of the other eleven galleries of the IAMM is followed by a selection of some of the most significant and fascinating artefacts in their respective collections.

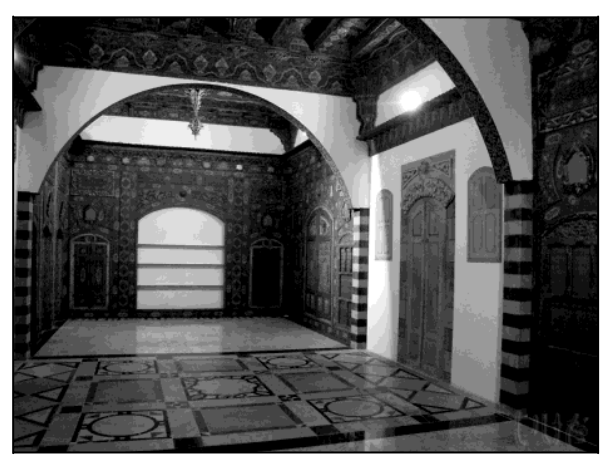

Figure 10. A $19^{\text {th }}$ century room from an Ottoman Syrian noble house

\section{Conservation of Heritage}

Prophet Mohammad peace be upon him stated: "Record and preserve the words that you hear from me and deliver it to the next generations." In this alighting statement lays indications to honor and respect the past and also value and honor the future. The effects and sparkles of identity in the past monuments and writings, especially architecture is in itself valuable, and honoring this value is respecting the present, respecting the past and respecting the future and with the misconceived aspects of it, is a source to reflect upon and an intermediary for knowledge and consciousness ${ }^{8}$.

Artistic and cultural heritage objects worldwide are affected by the conditions in which they exist. None is free from the ravages of time and environment. In Southeast Asia, in particular, there is a need for suitable conservation facilities with qualified and skilled professionals to conduct concerted efforts to preserve heritage. As an educator and a custodian of Islamic art and crafts for present and future generations, the IAMM museum has to take a key role in conservation, restoration, and preservation of artifacts (Figure 11).

Through research and training, the IAMM Conservation Centre furthers knowledge and information management on conservation. The conservation centers at IAMM presented a unique opportunity to asses and conserve every piece of the museum collection, as well as to prepare new materials for display and public access in permanent galleries or special one. The Conservation Centre spreads over 1,000 square meters and consists of 4 different laboratories, each dealing with different materials. All the laboratories are equipped with state-of-the-art equipments.

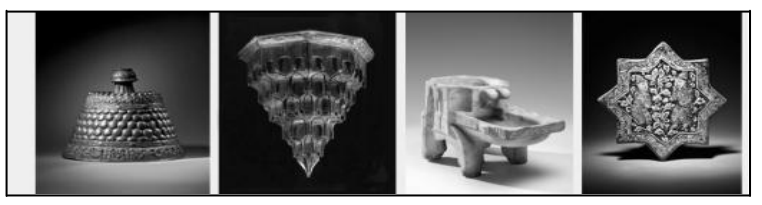

Figure 11. The museum has a key role in conservation, restoration, and preservation of its artifacts

This mammoth task of this center included the conservation of objects and experiment and researches on it. Treatment includes the conservation of paper, manuscripts, scrolls, metal work, textile, ceramics and glass as well as textiles and furniture.

\section{Audience and Facilities}

The interpretation of Islamic art and architecture is means by which the museum objects and displays are explained to the visitors. The Islamic Arts Museum Malaysia (IAMM) opened its doors to the public with the goal of fostering global understanding and appreciation of Islamic arts, culture and way of life, its mission is to be the custodian, preserver, restorer and educator of the Islamic Arts. The IAMM's public includes a wide range of audience types and learning styles social and intellectual; certain target audiences were selected in order to identify the needs of visitors: schools, students, professionals in creative industries, adults, families and groups (Figure 12).

The multicultural nature of Malaysian society is pertinent in responding to visitors need. Museum strive to make provision for all parts of society, it is essential to be aware of the nature and potential audiences and to create spaces as broad a range of visitors as possible. Auditorium is a venue that suits many purposes, it is ideal for lectures, seminars and conferences for organizing by museum or by external institutions. The restaurant is a another medium in creating the little atmosphere of Islamic traditional life and the soothing backdrop of the Fountain Garden Courtyard outside in addition to the range of dishes includes specialties from the Arab world and beyond. From the courtyard mosques in the dry arid lands of the Arab lands to the courtyard homes of 
the Middle East and Mediterranean, fountains are an integral part of both religious and domestic architecture. Besides the relief it provides from the heat and dust, water hold great significance in Islam and is thus both symbolically and physically represented in Islamic architecture. It is a symbol of cleanliness and happiness as well as the source of life whence creation springs. Islamic palaces and imperial grounds always include fountains and pools amidst lush greenery and flowering plants, evocative of images of paradise and the afterlife.

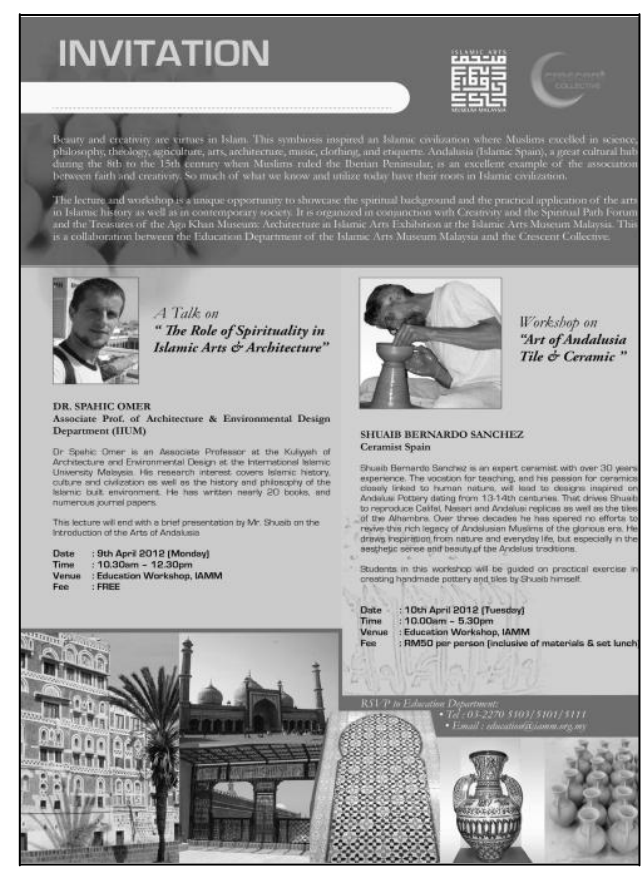

Figure 12. Public workshop for fostering global understanding of Islamic heritage

Inverted Dome Pavilion, located at one end of the Inverted Dome Lobby. The picturesque setting and impressive size of 648 square meters have caused the Inverted Dome Pavilion to serve numerous purposes. Among them are as a venue for exhibitions, receptions and product launches as well as telling a story about the concept of the dome forms and techniques ${ }^{9}$.

A rectangular enclosure, its three walls are comprised of floor to ceiling windows separated by white pilasters and framed in stainless steel rectangular bars. The center of each window is decorated with sand-blasted engraved images of the museum's ten-pointed star logo framed by the museum name in Kufi Banaie script. One of two major vantage points in the museum, the visitor is provided a clear view, towards the right, into the grounds of the National Mosque situated conveniently in front of the Museum, with the Kuala
Lumpur skyline providing a backdrop of contrast. Towards the left, one is confronted with the soothing vision of the treetops of the Kuala Lumpur Bird Park beyond the rich foliage of the Museum grounds.

\section{Conclusion}

As a museum of Islamic art dedicated to the preservation of ancient cultures, built at a time when the world was at the brink of the $21^{\text {st }}$ century, it was imperative that the museum will be an environment that was sleek and modern. Islam is not only a religion, it is a way of life and as evident from the architecture of the Islamic Arts Museum Malaysia and the artifacts that are on display in the respected galleries of this building, it does not purport to eradicate one's culture but instead, enriches it. If these architecture and artifacts are able to marry both culture and belief so successfully, let it be a lesson to all that function and form, culture and belief and above all, tolerance and understanding can co-exist which will then lead to peace and harmony. However, the IAMM Museum is a learning centre and a place for Muslims and nonMuslims young and old people to congregate and exchange ideas for the betterment of mankind irrespective of religious backgrounds.

All in all, in the past 10 years since its official opening, the museum has rapidly developed into a centre of education, heritage preservation and cultural exchange. Through its activities it will continue in its dedicated efforts to impart knowledge, and to foster global understanding and an appreciation of the arts, architecture and lifestyles of Islamic civilization.

\section{Recommendation}

This paper focused on the Islamic Arts Museum Malaysia and its experience in recognition of the importance of architecture to the artistic traditions of the Islamic world. It will be useful to consider some issues that are being experienced with this museum to end up with some recommendations. These recommendations could be as guidelines that will be useful for future in order to revive the Islamic art and architecture in different regions of the Muslim world. Thus, these recommendations are as follows:

1. Museums are places of great interest to educated people; educational program may serve to promote public awareness about significance of architectural heritage and the responsibility they 
as citizens should take upon themselves in his respect.

2. Educational programs in museums are meant for all audiences of the society, there should be encouragement to establish special programs to teach conservation of buildings, traditional techniques and materials.

3. Conservation of Architectural heritage is not only renovation of buildings it is also vast variety of other manifestations of material and immaterial heritage that are so exiting to discover and vital to safeguard. Therefore, there should be ways to foster this philosophy for young generations.

4. The rich Islamic architectural heritage is a manifestation of knowledge and revelation of truth which has the ability to enhance the extents of awareness of the educational system for teaching architecture. it is deeply convinced that introduction of heritage module into the curriculum of primary and secondary schools will very soon become an invaluable tool in the process of constructing children's identity in such a way that will guarantee their conscientious attitude towards the memory of their native communities.

5. Many pieces of architecture in the Muslim world are kept with individual collectors, these objects are in fair condition need a special care, museums and established institutions on conservation works are called for emergency intervention to preserve and restore this heritage which considered as a memory of Muslim Ummah.

\section{Acknowledgment}

This paper would not succeed without the intellectual contributions, work and support of many individuals to whom I am most grateful and indebted. I would like to express the deepest gratitude to all of my colleagues in different departments of IAMM. My appreciation goes to the director office of Islamic arts museum of giving me an opportunity to work in the museum and access to all collections and facilities for continues three years. Finally also acknowledge my heartiest gratitude to Al-Bukhary foundation for its support.

\section{References}

1 IAMM. 2002. Islamic Arts Museum Malaysia - Vol I. Kuala Lumpur: Islamic Art Museum Malaysia Publications.

2 Andrew, Peterse. 1996. Dictionary of Islamic Architecture. London: Printed by Routledge.

3 IAMM. 2002. Islamic Arts Museum Malaysia - Vol I. Kuala Lumpur: Islamic Art Museum Malaysia Publications.

4 De Ghuise, Lucien. 2005. Islamic Art Museum Malaysia Guide Book. Kuala Lumpur: Islamic Art Museum Malaysia Publications.

5. De Ghuise, Lucien. 2005. Islamic Art Museum Malaysia Guide Book. Kuala Lumpur: Islamic Art Museum Malaysia Publications

6. IAMM. 2009. Islamic Arts Museum Malaysia - Vol II. Kuala Lumpur: Islamic Art Museum Malaysia Publications

7. IAMM. 2009. Islamic Arts Museum Malaysia - Vol II. Kuala Lumpur: Islamic Art Museum Malaysia Publications

8. Mardomi K., Mohammad Moradi A. (2008). The Necessity to Value Cultural Heritage in Architectural Education International Journal Of Engineering Science, (Persian) ; 19(6):105-110

9. IAMM. 2002. Islamic Arts Museum Malaysia - Vol I. Kuala Lumpur: Islamic Art Museum Malaysia Publications. 